\title{
FORECASTING OF CO2 WITH THE EFFECT OF RENEWABLE ENERGY, NON-RENEWABLE ENERGY, GDP AND POPULATION FOR TURKEY: FORECASTING WITH NMGM $(1, \mathbf{N})$ GRAY FORECASTING MODEL ${ }^{1}$
}

Article Submission Date: 08.09.2021

Özlem KARADAĞ

ALBAYRAK

Asst. Prof.

Kafkas University

Faculty of Economics and

Administrative Sciences,

Kars, Turkey

ozlemkaradagalbayrak@gmail.com

ORCID ID: 0000-0003-0832-0490
Accepted Date: 21.11.2021

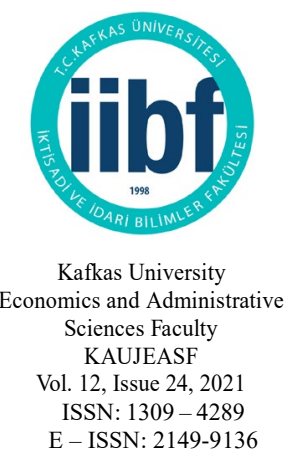

ABSTRACTI Carbon dioxide

emission is one of the important factors that have a negative impact on the environment. One of the reasons why policy makers produce incentive policies on renewable energy is that they want to reduce $\mathrm{CO} 2$ emissions. From this point of view, prediction of $\mathrm{CO} 2$ emissions must be made depending on different factors, and new policies can be developed and implemented according to the prediction results. In this article, a new approach from gray estimation models, NMGM $(1, N)$ forecasting model, is used to measure the impact of renewable energy consumption, nonrenewable energy consumption, GDP and Population factors on $\mathrm{CO} 2$ emission over time. 2006-2015 data was simulation set and 20162019 data was used as a test set. In addition to this method, estimation was made with GM (1, $\mathrm{N})$ and econometric model, which is the multivariate gray estimation method, and the results were compared. As a result, NMGM (1, $\mathrm{N})$ model has become a very effective estimation method with very low deviation values.

Keywords: Multivariate grey prediction model, NMGM (1, n), econometric models, co2 emissions, renewable energy consumption, nonrenewable energy consumption, GDP, population.

Jel codes: $C 13, Q 53, C 44$

Scope: Business

Type: Research

DOI: 10.36543/kauiibfd.2021.033

Cite this Paper: Karadağ Albayrak, Ö. (2021). Forecasting of CO2 with the effect of renewable energy, non-renewable energy, GDP and population for Turkey: forecasting with NMGM $(1, \mathrm{n})$ gray forecasting model. KAUJEASF, 12(24), 810-828.

${ }^{1}$ Compliance with the ethical rules of the relevant study has been declared. 


\section{TÜRKIYYE'DE CO2 EMISYONUNUN YENILENEBILIR ENERJI TÜKETIMI, YENILENEMEZ ENERJİ TÜKETIMI, GSMH VE NÜFUS ETKISII İLE TAHMINI: NMGM $(1$, N) GRİ TAHMIN MODELI}

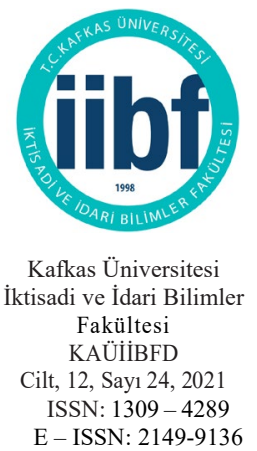

Özlem KARADAĞ

ALBAYRAK

Dr. Öğr. Üyesi

Kafkas Üniversitesi

İktisadi ve İdari Bilimler Fakültesi, Kars, Türkiye

ozlemkaradagalbayrak@gmail.com

ORCID ID: 0000-0003-0832-0490
ÖZI Karbondioksit salınımı çevre üzerinde olumsuz etkisi olan önemli faktörlerden birisidir. Politika yapıcıların yenilenebilir enerji konusunda teşvik politikaları üretmelerinin nedenlerinden biri de $\mathrm{CO} 2$ emisyonlarını azaltmayı istemeleridir. $\mathrm{Bu}$ noktadan hareketle $\mathrm{CO} 2$ emisyonlarının farklı faktörlere bağlı olarak tahmini yapılmalı ve tahmin sonuçlarına göre yeni politikalar geliştirilip uygulanmalıdır. $\mathrm{Bu}$ makalede, yenilenebilir enerji tüketimi, yenilenemeyen enerji tüketimi, GSMH ve Nüfus faktörlerinin zaman içinde $\mathrm{CO} 2$ emisyonu üzerindeki etkisini ölçmek için gri tahmin modellerinden yeni bir yaklaşım olan NMGM $(1, \mathrm{~N})$ tahmin modeli kullanılmıştır. Bu çalışmada 2006-2015 verisi similasyon seti, 2016-2019 verileri test seti olarak kullanılmıştır. Bu yönteme ek olarak GM $(1, N)$ ve çok değişkenli gri tahmin yöntemi olan ekonometrik model ile tahmin yapılmış ve sonuçlar karşılaştırılmıştır. Sonuç olarak NMGM $(1, N)$ tahmin modeli çok düşük sapma değerleri ile oldukça etkili bir tahmin sunmuştur.

Anahtar Kelimeler: Çok değişkenli gri tahmin modeli, NMGM $(1, N)$, ekonometrik modeller, co2 emisyonlarl, yenilenebilir enerji tüketimi, yenilenemez enerji tüketimi, GSYIH, nüfus.

JEL Kodu: C13, Q53, C44

Alan: Işletme

Türü: Araştırma 


\section{List of Abbreviations Including Units and Nomenclature}

RE: Renewable Energy

Non-RE: Non-Renewable Energy

NMGM: New Multivariable Grey Prediction Model

CO2: Carbon dioxide Emission

GDP: Gross Domestic Product

UP: Population

BP: British Petroleum

WB: World Bank 


\section{INTRODUCTION}

\subsection{Motivation}

$\mathrm{CO} 2$ emissions are one of the major environmental problems because not only it harms human beings but also contributes to climate change. Since $\mathrm{CO} 2$ emission has the largest share in greenhouse gases, it is one of the main determinants of climate change.

2019 has been the second hottest year of the last 10 years. Global temperatures are expected to rise between 1.5 and 5 degrees Celsius in many countries between 2030 and 2050. 194 countries that are members of the Paris Agreement have agreed to take action against greenhouse gas emissions and climate change threats to combat climate change. Among the greenhouse gases that cause climate change, the most important is $\mathrm{CO} 2$ emission. The three countries with the highest $\mathrm{CO} 2$ emission rates in the world are China (28\%) and the United States (15\%) and India (\%7).

According to IEA's Global Energy Review 2021 report, While the share of renewable energy sources in energy generation was less than $27 \%$ in 2019 , it will reach a record with $30 \%$ in 2021 . In $2020, \mathrm{CO} 2$ emissions fell more than energy demand as demand for oil and coal declined due to the COVID outbreak, on the contrary, renewables increased. Global $\mathrm{CO} 2$ emissions were reduced by $5.8 \%$ in 2020 .

However, in 2021, global energy-related $\mathrm{CO} 2$ emissions are expected to increase by $4.8 \%$ as the demand for coal, oil and gas increases with the economic growth. $80 \%$ of the expected increase in coal use is from the Asian continent under the leadership of China.

Turkey causes the almost $1 \%$ of world CO2 emissions (ESSD, 2019). Therefore, it struggles to reduce $\mathrm{CO} 2$ emission to target point. Therefore, studies on $\mathrm{CO} 2$ emissions reduction draw both researchers and policy makers attention. Estimation of $\mathrm{CO} 2$ emissions made by considering different estimation methods make great contributions to emission reduction policies policymakers deal with for a cleaner world.

When the share of resources in electricity generation between 2000 and 2019 are examined (Fig 1), it has been observed that the consumption rate of primary energy resources other than coal has decreased, while the consumption of renewable energy resources has increased. 


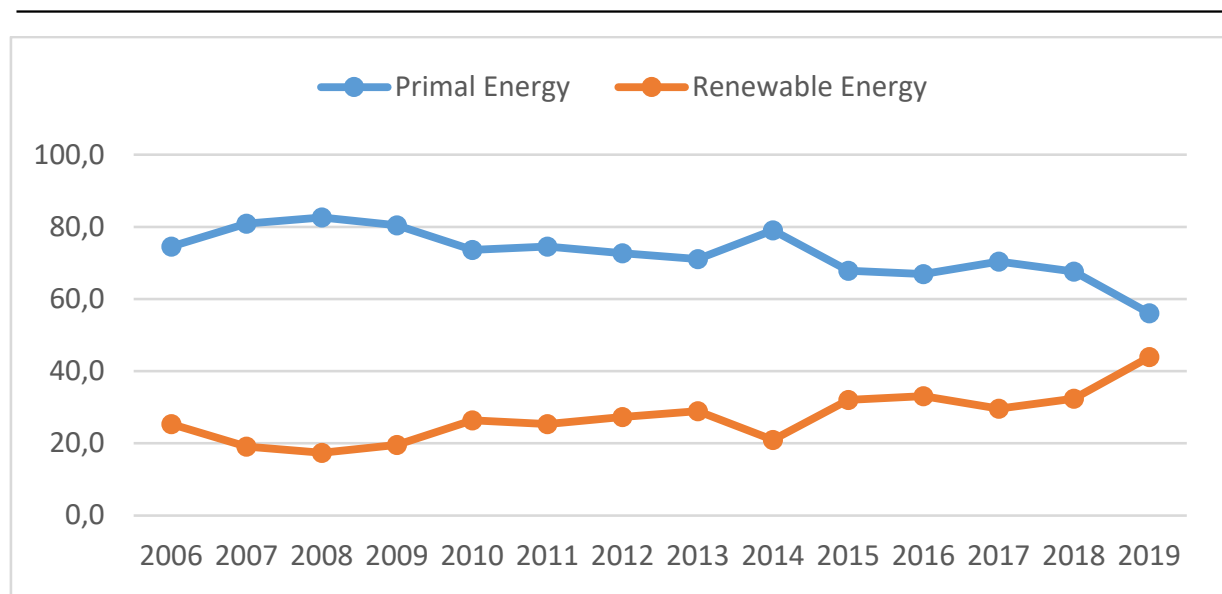

Fig 1. The share of Primary Energy and Renewable Energy in Total consumption (2006-2019)

In Turkey, coal had biggest share in primary energy resources before investments to renewable energy has risen. As shown in fig 2 . below, while coal maintained its stability, renewable resources, excluding hydraulics increased to $14.7 \%$ from $0.3 \%$ between $2000-2019$.

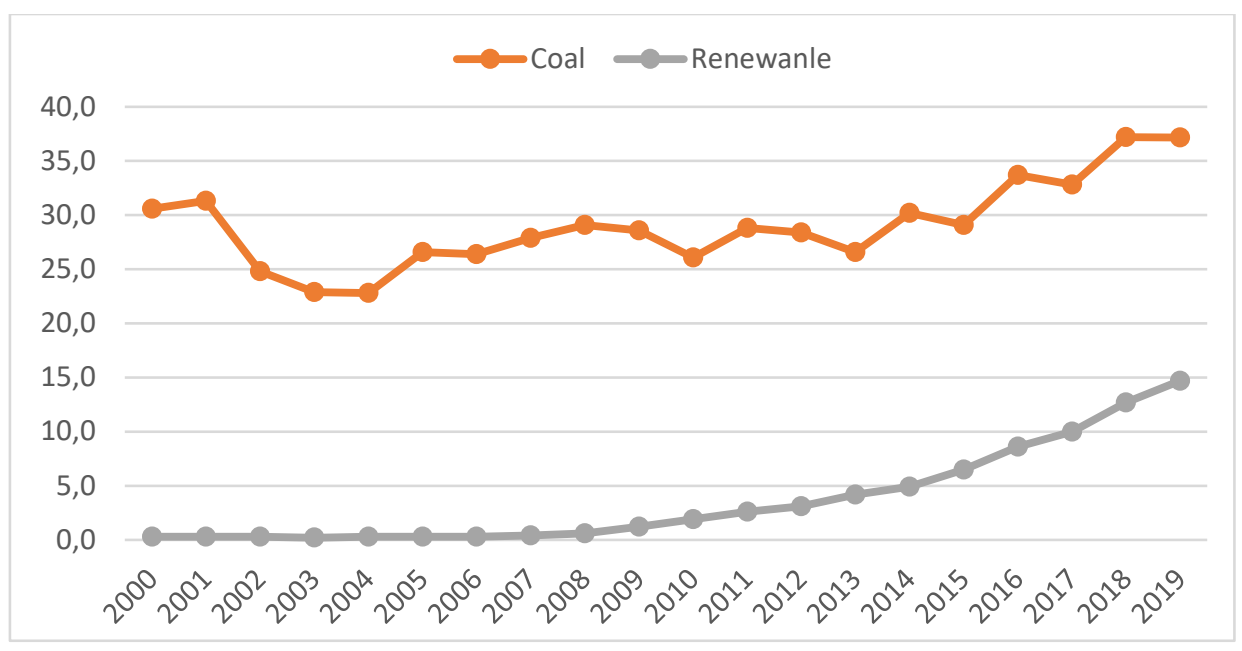

Fig 2. The comparison of Coal and Renewable Energy in Total consumption, \% (2000-2019) 
Considering the estimations mentioned above, Turkey should take necessary precautions for the expected increase in $\mathrm{CO} 2$ emissions for years to come. The aim of the study is to estimate $\mathrm{CO} 2$ emission for Turkey, and also to suggest for policy makers for the measures to be taken.

\subsection{Literature}

In the literature, statistical and artificial intelligence (software computing) based models are generally used for estimating time series data. Gray prediction models are advantageous in reaching accurate results in systems with less data than the traditional statistical prediction models. Artificial neural networks, one of the artificial intelligence-based applications, require a large amount of training data and relatively long training time to make a solid generalization (Jo, 2003). Traditional statistical models require more than 30 data for modelling (Ding et al, 2017). In this study, as other renewable sources other than hydraulic sources in Turkey; Energy consumption data set from sources such as wind, solar and geothermal is scarce, Gray forecasting models were preferred. Gray prediction models can be expressed as the curve fitting approach. In these models, the future prediction is made based only on the most recent data, depending on the estimator's window size. In gray models, the assumptions that all data values are positive and show time series feature should have been realized (Kayacan et al., 2010).

Gray estimation models, one of the important components of the gray system theory proposed by Deng (1982), have been widely used in different areas in recent years. GM $(1,1)$ models were first applied. Later, $\mathrm{GM}(1, \mathrm{~N})$ models were developed to be examined under the influence of other factors. GM $(1, N)$ model is a gray system estimation model with more than one variable and first order equation (Liu \& Lin, 2010). The multivariate grey model process takes into consideration the development trend of the system characteristic sequence, and makes full use of the limited in-formation contained in the relevant factor sequences. Therefore, the multivariate grey model is more suitable for prediction of $\mathrm{CO} 2$ emissions than the univariate grey model (Xie, 2021).

The univariate gray prediction model GM $(1,1)$ model is represented by a variable and a first order equation, the modelling object is a single time series ( Zeng et al, 2016). The effect of any other factors cannot be observed with this model (Wang and Hao, 2016). Zeng et al. (2016) suggests that the structure of the GM $(1, \mathrm{~N})$ model has some defects. These defects are, the final time-response expression of the GM $(1, \mathrm{~N})$ model is obtained by an ideal simplification process that may lead to the instability of the $\operatorname{GM}(1, \mathrm{~N})$ model. It is also the dislocation between parameter estimation and parameter execution. The structure of the model to be used for forecasting is an important factor affecting the performance 
of the model. Weakness of the model leads to poor simulation and predictive performance of the model. The performance of $\operatorname{NGMG}(1, \mathrm{~N})$ model is reasonable and effective (Zeng et al, 2020). For this reason, NGMG (1, N) model has been applied in this study.

The determinants of $\mathrm{CO} 2$ emissions are widely studied. Evaluation is made by considering different methods and factors and the results are discussed. Asumadu and Owusu (2017), For Rwanda, they investigated the relationship between GDP, population and industrialization factors with CO2. It has been concluded that GDP has an emission-reducing effect and industrialization has an emission-increasing effect. Nathaniel and Iheonu (2019), examined the effect of RE consumption, Non-RE consumption, GDP, Trade and domestic credit to the private sector factors on $\mathrm{CO} 2$ emission reduction for 19 African countries and obtained different country-specific results.

In the literature, there are different studies on the $\mathrm{CO} 2$ emission estimation made by applying the Gray System theory. In most of these studies, more methods were applied and the results were compared. Wang and Ye (2017) and Pao et al. (2017) estimated CO2 emissions from fossil energy consumption using nonlinear gray multivariate models and the ARIMA model. Pai et al. (2015) estimated $\mathrm{CO} 2$ emission amounts using multivariate gray prediction models and artificial neural networks. Ding et al (2017) Using a multivariate gray prediction model for China, they estimated the $\mathrm{CO} 2$ emissions by fossil fuel consumption, GDP and population factors. Ye et al (2021) applied a new time delay multivariate gray model to analyze the impact of $\mathrm{CO} 2$ emissions from China's transportation sectors. For the transport sector, energy consumption and freight turnover have an increasing effect on carbon emissions, while GDP and passenger turnover have a reducing effect on emissions. Yilmaz and Yilmaz (2013), Hamzaçebi and Karakurt (2015), GM $(1,1)$ by applying the models have predicted that Turkey's CO2 emissions. Xie et al. (2021), by applying the RWGM $(1, \mathrm{~N})$ model, they have estimated the energy according to many different factors. $\mathrm{Xu}$ et al (2020) estimated carbon dioxide emissions from energy consumption in 53 countries and regions using a non-equigap gray model. Shaheen et al. (2020) analyzed the determinants of $\mathrm{CO} 2$ emissions for Pakistan using a gray forecast model nad they concluded that GDP and energy use increased the emission.

When looking at the studies in the literature, it is thought that $\mathrm{CO} 2$ emissions are related to energy GDP, Population and Energy use. This study will investigate the relationship between factors for Turkey. The selected variables as determinants of $\mathrm{CO} 2$ emissions, renewable energy consumption (Pao et al., 2011, Pao et al., 2012, Wu et al, 2015), non-renewable energy consumption (Pao et al., 2011, Pao et al., 2012, Wu et al, 2015, Ding et al, 2017), GDP (Pao et al., 2011, 
Pao et al., 2012, Wu et al, 2015, Ding et al, 2017) and UP (Wu et al, 2015, Ding et al, 2017).

\subsection{Contribution and organization}

Major innovations are shown as follows:

1) The impacts of RE, NRE, P and GDP considered as decisive of $\mathrm{CO} 2$ emissions are determined with the proposed model for Turkey

(2) In this study, an empirical analysis and comparison was made with 2006-2019 data. Estimation results based on $\operatorname{NMGM~}(1, \mathrm{~N})$, traditional GM (1, $\mathrm{N})$ and econometric regression model were compared. The efficiency of the applied NMGM $(1, \mathrm{~N})$ model was measured.

(3) With this model, the reflection of the changes that will occur in the effects of the factors mentioned above on the carbon emission can be followed.

The rest contents are arranged as follows: Section 2 introduces the $\operatorname{NMGM}(1, \mathrm{~N})$ model. Section 3 carries out an empirical analysis on the $\mathrm{CO} 2$ in Tukey and compares the prediction effects of the traditional $\operatorname{GM}(1, \mathrm{~N})$ model, NMGM $(1, N)$ model and econometric model. The Discussion and Conclusion are made in Section 4.

\section{MATERIAL AND METHODS}

A novel multi-variable grey forecasting model NMGM $(1, \mathrm{~N})$ based on the smooth generation of independent variable sequences with variable weights was constructed (Zeng et al, 2020).

New Multivariable Grey prediction Model with structure compatibility, abbreviated as $\operatorname{NMGM}(1, \mathrm{~N})$ (Novel Multi-variable Grey Model) (Zeng et al, 2019).

Step 1. Creating dependent and independent variable sequences

$X_{1}^{0}(n)=\left(X_{1}^{0}(1), X_{1}^{0}(2), X_{1}^{0}(3), \ldots, X_{1}^{0}(n)\right)$

$X_{i}^{0}(n)=\left(X_{i}^{0}(1), X_{i}^{0}(2), X_{i}^{0}(3), \ldots, X_{i}^{0}(n)\right), i=2,3, \ldots . N$

$(\mathrm{n}=$ sample size $)$

Step 2. While AGO is a cumulatively produced series, with the 1-AGO operator, monotonously increasing series are obtained.

$X_{1}^{1}(n)=\left(X_{1}^{1}(1), X_{1}^{1}(2), X_{1}^{1}(3), \ldots, X_{1}^{1}(n)\right)$

$X_{i}^{1}(n)=\left(X_{i}^{1}(1), X_{i}^{1}(2), X_{i}^{1}(3), \ldots, X_{i}^{1}(n)\right), i=2,3, \ldots . N$

1-AGO operator is calculated as follows.

$X_{1}^{1}(k)=\sum_{t=1}^{k} X_{1}^{0}(t), k=1,2, \ldots, n$

$X_{i}^{1}(k)=\sum_{t=1}^{k} X_{i}^{0}(t), k=1,2, \ldots, n$ and $\left.i=2,3, \ldots, N\right)$ 
Step 3. NMGM $(1, \mathrm{~N})$ model is established.

$X_{1}^{1}(k)=\sum_{i=2}^{N} b_{i} X_{i}^{1}(k)+\beta_{1} X_{1}^{1}(k-1)+\beta_{2}(k-2)+\beta_{3}$

Step 4. Its parameters $\hat{P}=\left[b_{2}, b_{3}, \ldots, b_{N}, \beta_{1}, \beta_{2}, \beta_{3}\right]^{T}$ are calculated with the Least Squares method.

$$
\begin{aligned}
& B=\left[\begin{array}{ccccccc}
X_{2}^{1}(2) & X_{3}^{1}(2) & \ldots & X_{N}^{1}(2) & X_{1}^{1}(1) & 1 & 1 \\
X_{2}^{1}(3) & X_{3}^{1}(3) & \ldots & X_{N}^{1}(3) & X_{1}^{1}(2) & 2 & 1 \\
\vdots & \vdots & \vdots & \vdots & \vdots & \vdots & \vdots \\
X_{2}^{1}(m) & X_{3}^{1}(m) & \ldots & X_{N}^{1}(m) & X_{1}^{1}(m-1) & m-1 & 1
\end{array}\right] \\
& Y=\left[\begin{array}{c}
X_{1}^{1}(2) \\
X_{1}^{1}(3) \\
\vdots \\
X_{1}^{1}(m)
\end{array}\right]
\end{aligned}
$$

Then the least squares estimate of the sequence of parameters satisfies,

(i): if $m=N+3$ and $|B| \neq 0$ then $\hat{P}=B^{-1} Y$;

(ii): if $m>N+3$ and $\left|B^{T} B\right| \neq 0$ then $\hat{P}=\left(B^{T} B\right)^{-1} B^{T} Y$;

(iii): if $m<N+3$ and $\left|B B^{T}\right| \neq 0$ then $\hat{P}=B^{T}\left(B B^{T}\right)^{-1} Y$;

Step 5. To simulate the value of $\hat{X}_{1}^{1}(k)$, the time response function is calculated as follows.

$$
\begin{aligned}
& \hat{X}_{1}^{1}(k)=\sum_{u=1}^{k-1}\left[\sum_{i=2}^{N} \beta_{1}^{u-1} b_{i} X_{i}^{1}(k-u-1)\right]+B_{1}^{k-1} \hat{X}_{1}^{1}(1)+ \\
& \sum_{v=0}^{t-2} \beta_{1}^{k-2}\left[(k-v-1) \beta_{2}+\right. \\
& \left.\beta_{3}\right], k=2,3, \ldots, m .
\end{aligned}
$$

Step 6. To determine the exact value $\widehat{X}_{1}^{0}(k)$, the following equation is used.

$$
\hat{X}_{1}^{0}(k)=\hat{X}_{1}^{1}(k)-\hat{X}_{1}^{1}(k-1), k=2,3, \ldots, n
$$

Step 7. The \% deviation in the training set and test set estimates is calculated as follows.

$\Delta(k)=\frac{\left|\hat{X}_{1}^{0}(k)-X_{1}^{0}(k)\right|}{X_{1}^{0}(k)} * 100, k=1,2, \ldots, n$ 


\section{RESULTS}

\subsection{Data Set}

In this study, we used the $\mathrm{CO} 2$ (Million tonnes of carbon dioxide), RE consumption (Exajoules) and RE consumption (Energy consumption from renewable sources includes the consumption of hydraulic energy- Exajoules) which were obtained from the energy-related internet site of British Petroleum company (BP, 2020), GDP per capita (constant 2010 US\$) which were obtained from World Bank. (WB, 2020) and UP (Population) which were obtained from Turkish Statistical Institute (TSI, 2020). The original values of the data are shown in Table 1.

In this study, the reason for so much less of the data set is a short history of consumption of renewable energy resources for Turkey. Renewable energy consumption has a significant impact on $\mathrm{CO} 2$ emission reduction. Therefore, it is one of the main factors of this study. Although hydraulic energy production has been continuing for about 40 years, compared to hydraulic resources, the use of solar, wind, biomass and geothermal resources is very new.

The original values of the data set have different sizes and units. Unlike univariate gray models, multivariate gray models may have shifts in data matrices while defining parameters. To avoid this, the original data set is arranged in order of magnitude. For the order of magnitude, the data can be obtained by a specific method, transforming using the initial value or the mean value (Wang \& Ye, 2016).. In this model, the year 2006 is taken as the first point of the system as the special processing method for transformation in the initial data. Data from 2006 is divided by data from 2006 to 2019 . The data after the initialization process is given in Table 2. 
Table 1. Original data of CO2, RE, Non-RE, GDP and UP, Turkey

\begin{tabular}{cccccc}
\hline Years & CO2 & RE & NRE & GDP & UP \\
& $X_{1}^{0}$ & $X_{2}^{0}$ & $X_{3}^{0}$ & $X_{4}^{0}$ & $X_{5}^{0}$ \\
\hline 2006 & 248,0 & 0,43 & 3,95 & 10340,072 & 69729967 \\
2007 & 272,8 & 0,35 & 4,21 & 10732,787 & 70586256 \\
2008 & 276,3 & 0,33 & 4,22 & 10691,689 & 71517100 \\
2009 & 275,3 & 0,36 & 4,28 & 10047,204 & 72561312 \\
2010 & 276,3 & 0,52 & 4,50 & 10742,43 & 73722988 \\
2011 & 298,8 & 0,54 & 4,81 & 11763,935 & 74724269 \\
2012 & 314,4 & 0,61 & 5,11 & 12127,586 & 75627384 \\
2013 & 303,3 & 0,65 & 5,07 & 12935,687 & 76667864 \\
2014 & 335,1 & 0,49 & 5,23 & 13345,591 & 77695904 \\
2015 & 340,6 & 0,77 & 5,72 & 13923,683 & 78741053 \\
2016 & 359,0 & 0,82 & 6,01 & 14153,463 & 79814871 \\
2017 & 397,1 & 0,79 & 6,37 & 14975,087 & 80810525 \\
2018 & 392,1 & 0,88 & 6,29 & 15190,099 & 82003882 \\
2019 & 383,3 & 1,21 & 6,49 & 15125,391 & 83154997 \\
\hline
\end{tabular}

Table 2. The sequences variables after initialization

\begin{tabular}{cccccc}
\hline Years & CO2 & RE & NRE & GDP & UP \\
& & & & & \\
& $X_{1}^{0}$ & $X_{2}^{0}$ & $X_{3}^{0}$ & $X_{4}^{0}$ & $X_{5}^{0}$ \\
\hline 2006 & 1,0000 & 1,0000 & 1,0000 & 1,0000 & 1,0000 \\
2007 & 1,0999 & 0,8134 & 1,0637 & 1,0380 & 1,0123 \\
2008 & 1,1144 & 0,7636 & 0,0000 & 1,0340 & 1,0256 \\
2009 & 1,1101 & 0,8399 & 1,0816 & 0,9717 & 1,0406 \\
2010 & 1,1142 & 1,2190 & 1,1386 & 1,0389 & 1,0573 \\
2011 & 1,2050 & 1,2644 & 1,2168 & 1,1377 & 1,0716 \\
2012 & 1,2679 & 1,4160 & 1,2916 & 1,1729 & 1,0846 \\
2013 & 1,2230 & 1,5231 & 1,2817 & 1,2510 & 1,0995 \\
2014 & 1,3514 & 1,1369 & 1,3234 & 1,2907 & 1,1142 \\
2015 & 1,3733 & 1,7852 & 1,4477 & 1,3466 & 1,1292 \\
2016 & 1,4476 & 1,9135 & 1,5204 & 1,3688 & 1,1446 \\
2017 & 1,6013 & 1,8404 & 1,6120 & 1,4483 & 1,1589 \\
2018 & 1,5810 & 2,0517 & 1,5908 & 1,4691 & 1,1760 \\
2019 & 1,5455 & 2,8084 & 1,6417 & 1,4628 & 1,1925 \\
\hline
\end{tabular}




\subsection{Forecasting Models}

In this study, NMGM $(1, N)$ Gray Prediction model proposed by Zeng et al (2019) was applied to estimate CO2 emission. With this prediction model, it is aimed to develop a meaningful estimation model for Turkey's $\mathrm{CO} 2$ emission estimation.

In the NMGM $(1, \mathrm{~N})$ multivariate gray prediction model, $\mathrm{CO} 2$ as the dependent variable and renewable energy consumption amount, non-renewable energy consumption amount, gross national product and population data were used as independent variables. Since this model consists of 1 dependent 4 independent variables, it will be expressed as $\operatorname{NMGM}(1,5)$ model.

In gray estimation, firstly, the data set is divided into training set or simulation set and test set. With the training set, the parameters necessary for the creation of the prediction model are estimated. Using the test set, it is monitored how closely the established prediction model predicts the correct one. In this study, the simulation set of time series data between 2006-2015 and time series data between dates 2016-2019 were divided into test set.

Step 1 matrices are presented in Table 2. Monotonously increasing series, cumulative set created for Step 2 is presented in Table 3. The parameters $\widehat{P}=$ $\left[b_{2}, b_{3}, \ldots, b_{N}, \beta_{1}, \beta_{2}, \beta_{3}\right]^{T}$ of the prediction model established in Step 3 were calculated as follows (Table 4 ). After the parameters are estimated, the prediction model in equation 7 is established. To simulate the value $\hat{X}_{1}^{1}(k)$ of the time response function is calculated (Eq 10) and then exact value $\hat{X}_{1}^{0}(k)$ are calculated (Eq 11). The regression model obtained with the econometric model is presented in Equation 12.

Table 5 presents the estimation results of the NMGM $(1,5)$ gray prediction model. With this estimation model, estimates have been made with GM $(1, N)$ and econometric models and the results are presented. In addition, the predictive power of each prediction model is expressed as percentage deviation in this table (Eq12). Scatter diagrams of these three models are presented in Figure 3. 
Table 3. Monotonously Increasing Series

\begin{tabular}{|c|c|c|c|c|c|c|}
\hline \multirow[t]{2}{*}{ k } & Year & $\mathrm{CO2}$ & $\mathbf{R E}$ & NRE & GDP & UP \\
\hline & & $X_{1}^{1}$ & $X_{2}^{1}$ & $X_{3}^{1}$ & $X_{4}^{1}$ & $X_{5}^{1}$ \\
\hline $\mathrm{k}=1$ & 2006 & 1,0000 & 1,0000 & 1,0000 & 1,0000 & 1,0000 \\
\hline $\mathrm{k}=2$ & 2007 & 2,0999 & 1,8134 & 2,0637 & 2,0380 & 2,0123 \\
\hline$k=3$ & 2008 & 3,2143 & 2,5770 & 2,0637 & 3,0720 & 3,0379 \\
\hline $\mathrm{k}=4$ & 2009 & 4,3244 & 3,4169 & 3,1453 & 4,0437 & 4,0785 \\
\hline $\mathrm{k}=5$ & 2010 & 5,4385 & 4,6358 & 4,2839 & 5,0826 & 5,1358 \\
\hline $\mathrm{k}=6$ & 2011 & 6,6436 & 5,9002 & 5,5007 & 6,2203 & 6,2074 \\
\hline $\mathrm{k}=7$ & 2012 & 7,9115 & 7,3163 & 6,7923 & 7,3932 & 7,2920 \\
\hline $\mathrm{k}=8$ & 2013 & 9,1345 & 8,8393 & 8,0740 & 8,6442 & 8,3915 \\
\hline $\mathrm{k}=9$ & 2014 & 10,4859 & 9,9763 & 9,3974 & 9,9348 & 9,5057 \\
\hline $\mathrm{k}=10$ & 2015 & 11,8593 & 11,7614 & 10,8451 & 11,2814 & 10,6349 \\
\hline $\mathrm{k}=11$ & 2016 & 13,3069 & 13,6749 & 12,3655 & 12,6502 & 11,7796 \\
\hline $\mathrm{k}=12$ & 2017 & 14,9082 & 15,5153 & 13,9775 & 14,0985 & 12,9385 \\
\hline $\mathrm{k}=13$ & 2018 & 16,4892 & 17,5670 & 15,5683 & 15,5675 & 14,1145 \\
\hline $\mathrm{k}=14$ & 2019 & 18,0347 & 20,3754 & 17,2100 & 17,0303 & 15,3070 \\
\hline
\end{tabular}

Table 4. $\hat{P}$ Parameters

\begin{tabular}{|c|c|c|c|c|c|c|}
\hline $\mathbf{b 2}$ & $\mathbf{b 3}$ & $\mathbf{b 4}$ & $\mathbf{b 5}$ & $\boldsymbol{\beta 1}$ & $\boldsymbol{\beta 2}$ & $\boldsymbol{\beta 3}$ \\
\hline$-0,0377$ & $-0,0432$ & 0,1984 & 2,9865 & $-0,1182$ & $-1,9949$ & $-2,0418$ \\
\hline
\end{tabular}

The weights between the $\mathrm{CO} 2$ emissions and 4 different control parameters (RE, Non RE, GDP and UP) were calculated as shown Table 4. The weights of CO2 were in the order: UP $(2,9865)>\operatorname{GDP}(0,1984)>\operatorname{RE}(-0,0377)$ $>$ Non RE $(-0,0432)$. 
Table 5. The simulation and prediction values of $\mathrm{CO}_{2}$ Emission for Three Models.

\begin{tabular}{|c|c|c|c|c|c|c|c|c|}
\hline \multirow[b]{2}{*}{ Data } & \multirow[b]{2}{*}{ Year } & \multirow{2}{*}{$\begin{array}{c}\mathrm{Co} 2 \\
\text { Real } \\
\text { Valu } \\
\text { e }\end{array}$} & \multicolumn{2}{|c|}{$\begin{array}{c}\text { NMGM(1,N) Grey } \\
\text { Model }\end{array}$} & \multicolumn{2}{|c|}{ GM(1,N) Grey Model } & \multicolumn{2}{|c|}{ Econometric Model } \\
\hline & & & $\begin{array}{l}\text { Simulatio } \\
\mathrm{n} \text { value }\end{array}$ & $\begin{array}{l}\text { Percentag } \\
\text { e Error }\end{array}$ & $\begin{array}{l}\text { Simulatio } \\
\mathrm{n} \text { value }\end{array}$ & $\begin{array}{l}\text { Percentag } \\
\text { e Error }\end{array}$ & $\begin{array}{l}\text { Simulatio } \\
\mathrm{n} \text { value }\end{array}$ & $\begin{array}{c}\text { Percentag } \\
\text { e Error }\end{array}$ \\
\hline \multirow{10}{*}{ 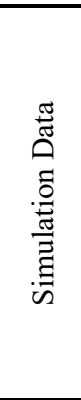 } & 2006 & 1,000 & - & - & - & - & - & - \\
\hline & 2007 & 1,100 & 1,101 & 0,14 & 0,988 & 10,17 & 1,064 & 3,30 \\
\hline & 2008 & 1,114 & 1,114 & 0,01 & 1,273 & 14,20 & 1,102 & 1,08 \\
\hline & 2009 & 1,110 & 1,095 & 1,32 & 1,172 & 5,55 & 1,081 & 2,62 \\
\hline & 2010 & 1,114 & 1,144 & 2,68 & 1,153 & 3,46 & 1,128 & 1,27 \\
\hline & 2011 & 1,205 & 1,196 & 0,78 & 1,215 & 0,85 & 1,211 & 0,50 \\
\hline & 2012 & 1,268 & 1,226 & 3,29 & 1,232 & 2,85 & 1,247 & 1,65 \\
\hline & 2013 & 1,223 & 1,279 & 4,59 & 1,285 & 5,04 & 1,316 & 7,58 \\
\hline & 2014 & 1,351 & 1,337 & 1,03 & 1,355 & 0,23 & 1,394 & 3,13 \\
\hline & 2015 & 1,373 & 1,357 & 1,22 & 1,350 & 1,70 & 1,413 & 2,86 \\
\hline \multicolumn{2}{|c|}{$\begin{array}{l}\text { Mean Error } \\
\text { (Simulation }\end{array}$} & & & 1,67 & & 4,89 & & 2,67 \\
\hline \multirow{4}{*}{ 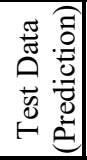 } & 2016 & 1,448 & 1,397 & & 1,364 & 5,77 & 1,448 & 0,01 \\
\hline & 2017 & 1,601 & 1,449 & & 1,438 & 10,20 & 1,527 & 4,66 \\
\hline & 2018 & 1,581 & 1,491 & & 1,441 & 8,84 & 1,560 & 1,34 \\
\hline & 2019 & 1,545 & 1,500 & & 1,380 & 10,73 & 1,540 & 0,38 \\
\hline \multicolumn{2}{|c|}{$\begin{array}{l}\text { Mean Error } \\
\text { (Prediction) }\end{array}$} & & & 5,40 & & 8,88 & & 1,60 \\
\hline \multicolumn{2}{|c|}{$\begin{array}{l}\text { Global } \\
\text { Error }\end{array}$} & & & 2,50 & & 6,12 & & 2,34 \\
\hline
\end{tabular}

When Table 5 is examined, NMGM $(1, N)$ model is a better estimator than GM $(1, \mathrm{~N})$ and econometric model. Because, Global deviation occurred in this model with the lowest value of 2.50 . The least effective prediction model is the GM $(1, N)$ model with a global deviation of 6,12 . Although the econometric model gives a lower deviation value, although the model is statistically significant, two of the parameters in the model are statistically insignificant. This is due to the multiple linear deviation between the independent variables. 


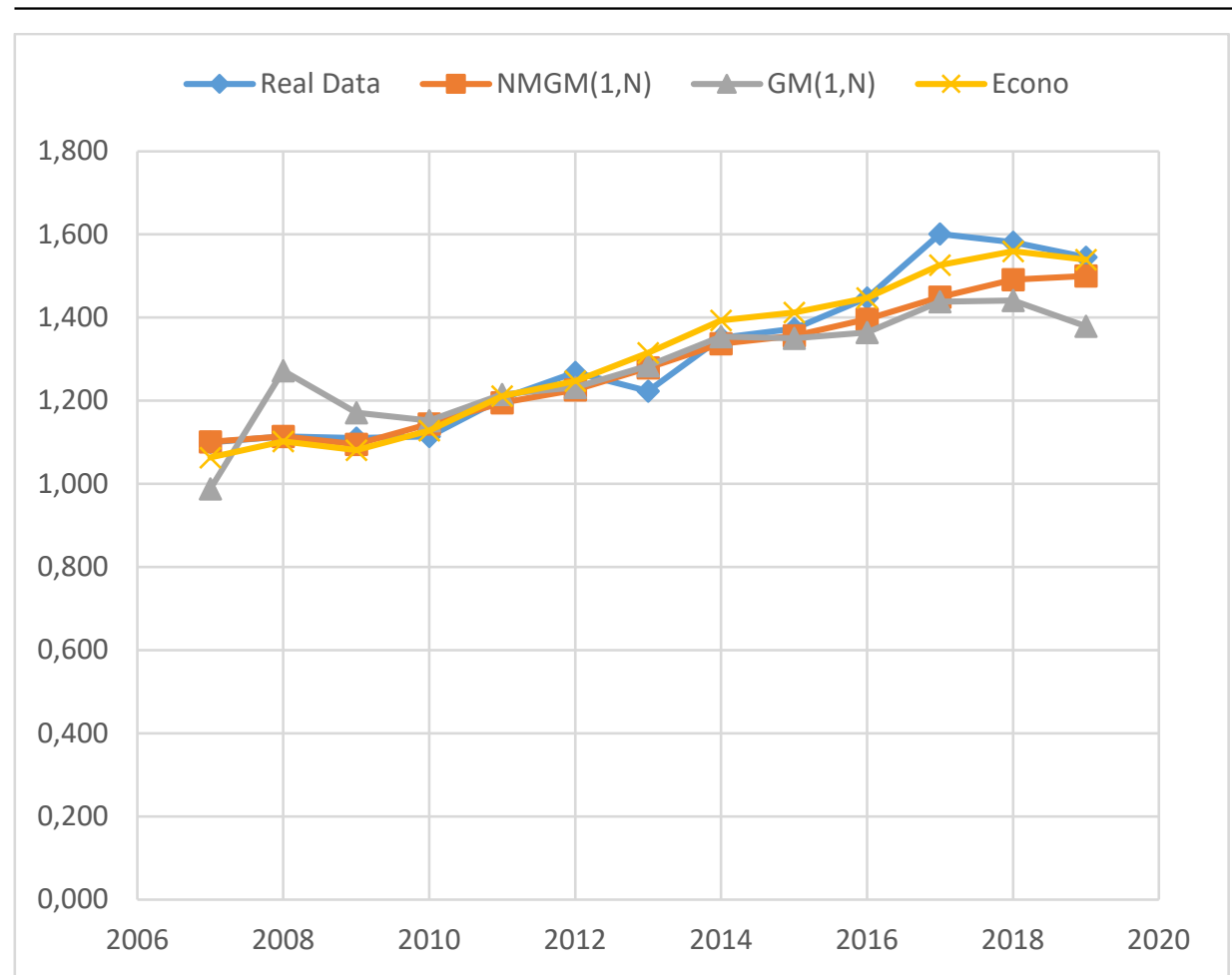

Fig 3. The line chart diagrams for Three Models and real data.

Using this model, $\mathrm{CO} 2$ emissions can be estimated according to changes in RE, NonRE, GDP and UP data for the coming years.

\section{DISCUSSION AND CONCLUSION}

Greenhouse gas emissions, one of the important causes of environmental problems, are very serious for the world to be left to future generations. The most important of these emissions is $\mathrm{CO}$ emissions. Turkey international environmental agreements such as the Kyoto protocol, like other countries, as well as cleaner air with Turkey is monitoring the $\mathrm{CO} 2$ emissions target. In this respect, it is very important to estimate the amount of $\mathrm{CO}$ emission that will occur due to different factors.

In this study, a model to estimate the $\mathrm{CO} 2$ emissions, considering four factors which are RE consumption amount, Non-RE consumption amount, GDP and population for Turkey was created. For this, time series data between 20062019 are used. The data is splitted into training dataset and test dataset. First one is used for simulation between 2006 and 2015 years. Second one is the test set 
for period of 2016-2019. The NGMG $(1, N)$ model used for estimation is effective compared to $\mathrm{GM}(1, \mathrm{~N})$ with a very low deviation value (about $2 \%$ ).

Renewable and non-renewable energy sources, GDP and the effects of the population on $\mathrm{CO} 2$ emissions have been investigated. The main results can be summarized as follow.

1. As the GDP increases, the $\mathrm{CO} 2$ emission increases. In other words, economic growth increases carbon emissions. Turkey may face an increase...

2. As the population increases, the $\mathrm{CO} 2$ emission increases. In other words, The rise of population in the country increases the carbon emission. It is expected that the population will increase the emission as consumption will increase. According to World Bank data; while the proportion of population to $75.1 \%$ in 2018 living in urban areas in Turkey, awareness of renewable energy in the urban population can be increased.

3. An inverse relationship has been observed between renewable energy consumption and carbon emission. In other words, renewable energy consumption will reduce $\mathrm{CO} 2$ emission. As expected from this findings, energy usage generated from renewable sources such as wind, solar, geothermal and biomass will reduce carbon emissions and other greenhouse gas emissions.

4. In contrary to what is expected, it is founded there is inverse relationship between fossil sourced energy consumption and emission, despite having a very low value (-0.0432). The negative relationship between the use of non-renewable energy sources and the carbon emission variable is incompatible with other results in the literature. Therefore, this may be important for researcher to study further. In future studies, both $\mathrm{CO} 2$ emission and renewable energy estimation will be made with different applications of gray prediction modules.

In literature, there are few studies in the literature that have demonstrated negative effects (Menyah and Wolde-Rufael, 2010, Sharma, 2011, Valadkhani, 2019). Nathaniel and Iheonu (2019) studied the impact of RE and Non-RE sources in reducing Carbon dioxide emissions for 19 African countries and obtained different country-specific results on the impact of Non-RE sources in countries. In Cameroon and Congo DR countries, they conclude that RE and Non$\mathrm{RE}$ energy consumption has a reducing effect on carbon emission. In this study, the unexpected nexus between primary energy consumption and emission is triggered from the rise of renewable energy with 50 times in opposition to almost constant share of coal. Furthermore, it was aimed to measure the effect of 
renewable energy factor, which has limited data, as well as other factors. The data set can be kept larger and the consumption factor of non-renewable energy sources can be analyzed again.

In the study, $\mathrm{CO} 2$ emission for coming years can be estimated with the model established. The emission impact of energy consumption, GDP and population change can be estimated. The results are presented to all the actors handling clean air target of Turkey. On October 7, 2021, the Paris Agreement was approved by our country. Decision makers can use the study data and models we provide to meet the requirements of this agreement, which aims to reduce emissions in general.

\section{STATEMENT OF CONFLICT OF INTEREST}

There is no conflict of interest between the authors. (Single Author)

\section{FINANCIAL SUPPORT}

No funding or support was used in this study.

\section{AUTHOR CONTRIBUTIONS}

ÖKA, Idea;

ÖKA: Design;

ÖKA: APPENDIX: Supervision;

ÖKA: Collection and/or processing of resources;

ÖKA: Analysis and/or interpretation;

ÖKA: Literature review;

ÖKA: Written by;

ÖKA: Critical review;

8. ETHICS COMMITTEE STATEMENT AND INTELLECTUAL PROPERTY COPYRIGHTS committee.

This is a study that does not require permission from the ethics

\section{REFERENCES}

Asumadu-Sarkodie S., Owusu P. A. (2017). Carbon dioxide emissions, GDP per capita, industrialization and population: an evidence from Rwanda. Environ. Eng. Res. 22(1), 116-124. doi: 10.4491/eer.2016.097.

Deng, J.L. (1982). Control problems of grey Systems. Systems \& Control Letters, 1, 288294. doi: 10.1016/S0167-6911(82)80025-X.

Ding S., Dang, Y-G., Li X-M., Wang J-J.\& Zhao K. (2017). Forecasting Chinese CO2 emissions from fuel combustion using a novel grey multivariable model. Journal of Cleaner Production 162, 1527-1538. doi: 10.1016/j.jclepro.2017.06.167.

Jo T. C., (2003,). The effect of virtual term generation on the neural based approaches to time series prediction. In Proceedings of the IEEE fourth conference on control and automation, Montreal (ss.516-520), Canada. doi: 10.1109/ICCA.2003.1595075 
Kamzaçebi C., Karakurt I. (2015).Forecasting the energy-related CO2 emissions of Turkey using a grey prediction model. Energy Sources, Part A: Recovery, Utilization, and Environmental Effects, 37, 1023-1031. 1031. doi: $10.1080 / 15567036.2014 .978086$

Kayacan, E., Ulutas, B. \& Kaynak, O., (2010). Grey system theory-based models in time series prediction. Expert Syst. Appl, 37, 1784-1789.doi: 10.1016/j.eswa.2009.07.064.

Liu. S. and Lin Y. (2010). Grey information theory and practical applications, SpringerVerlag, Berlin.

Menyah K. and Wolde-Rufael Y. (2010). Energy consumption, pollutant emissions and economic growth in south Africa, Energy Economics 32, 1374-1382. doi: 10.1016/j.eneco.2010.08.002

Nathaniel S. P. and Iheonu C. O. (2019). Carbon dioxide abatement in Africa: the role of renewable and non-renewable energy consumption. Science of the Total Environment 679, 337-345. doi: 10.1016/j.scitotenv.2019.05.011.

Pai, T.Y., Lo, H.M. \& Wan, T.J. (2015). Predicting air pollutant emissions from a medical incinerator using grey model and neural network. Appl. Math. Model. 39 (5), 1513-1525. doi: 10.1016/j.apm.2014.09.017

Pao, H.T., Fu, H.C. \& Tseng, C.L. (2012). Forecasting of CO2 emissions, energy consumption and economic growth in China using an improved grey model. Energy, 40, 400-409. Doi: 10.1016/j.energy.2012.01.037.

Pao, H.T., Tsai, C.M. (2011). Modeling and forecasting the CO2 emissions, energy consumption, and economic growth in Brazil. Energy 36 (5), 2450-2458. doi: 10.1016/j.energy.2011.01.032.

Sharma S. S. (2011). Determinants of carbon dioxide emissions: empirical evidence from 69 countries, Applied Energy 88, 376-382. doi: 10.1016/j.apenergy.2010.07.022.

Shaheen A., Sheng J., Arshad S., Muhammad H. \& Salam S. (2020). Forecasting the determinants of environmental degradation: a gray modeling approach. Energy Sources, Part A: Recovery, Utilization, And Environmental Effects Https:/Doi.Org/10.1080/15567036.2020.1827090

Valadkhani A., Smyth R .\& Nguyen J. (2019). Effects of primary energy consumption on $\mathrm{CO} 2$ emissions under optimal thresholds: evidence from sixty countries over the last half century. Energy Economics 80, 680-690. doi:10.1016/j.eneco.2019.02.010.

Xie M.,Yan S.,Wu L., Liu L., Bai Y., Liu L. \& Tong Y. (2021). A novel robust reweighted multivariate grey model for forecasting the greenhouse gas emissions. Journal of Cleaner Production 292, 126001. doi: 10.1016/j.jclepro.2021.126001.

$\mathrm{Xu}$ Z., Liu L. \& Wu, L. (2021). Forecasting the carbon dioxide emissions in 53 countries and regions using a non-equigap grey model. Environmental Science and Pollution Research, 28, 15659-15672. doi: 10.1007/s11356-020-11638-7. 
Wang, Z.X., Ye, D.J. (2016). Forecasting Chinese carbon emissions from fossil energy consumption using non-linear grey multivariable models. J. Clean. Prod. 142, 600-612. doi: 10.1016/j.jclepro.2016.08.067.

Wang, Z.X., Hao, P. (2016). An improved grey multivariable model for predicting industrial energy consumption in China. Applied Mathematical Modelling, 40 (11), 5745-5758. doi: 10.1016/j.apm.2016.01.012

Wu L., Liu S., Liu D., Fang Z. \& Xu H. (2015). Modelling and forecasting CO2 emissions in the Brics (Brazil, Russia,India, China, and South Africa) countries using a novel multi-variablegrey model. Energy, 79, 489-495490. doi: 10.1016/j.energy.2014.11.052.

Ye L., Xie N. \& Hu A. (2021). A novel time-delay multivariate grey model for impact analysis of $\mathrm{CO} 2$ emissions from china's transportation sectors. Applied Mathematical Modelling 91, 493-507. doi: 10.1016/j.apm.2020.09.045.

Yilmaz H. and Yilmaz M. (2013). Forecasting the energy-related co 2 emissions of Turkey using a grey prediction model. Sigma, 31, 141-148.

Zeng B., Duan H. \& Zhou Y. (2019). A new multivariable grey prediction model with structure compatibility, Applied Mathematical Modelling, 75, 385-397. doi:10.1016/j.apm.2019.05.044.

Zeng B., Luo C., Liu S., Bai Y.\& Li C. (2016). Development of an optimization method for the GM(1,N) model, Engineering Applications of Artificial Intelligence, 55, 353-362. doi: 10.1016/j.engappai.2016.08.007

Zeng B., Li H. \& Ma X. (2020).A novel multi-variable grey forecasting model and its application in forecasting the grain production in China. Computers \& Industrial Engineering, 150, 106915. doi: 10.1016/j.cie.2020.106915.

British Petroleum (BP). (2021). https://www.bp.com/en/global/corporate/energyeconomics/statistical-review-of-world-energy.html. Accessed on 17.06. 2021

World Bank (WB). (2021) https://databank.worldbank.org/source/world-developmentindicators. Accessed on 12.06. 2021

Turkish Statistical Institute (2021). https://tuikweb.tuik.gov.tr/UstMenu.do?metod=temelist. Accessed on 07.08. 2021

Earth System Science Data (ESSD). (2019). https://www.ucsusa.org/resources/eachcountrys-share-co2-emissions. Accessed on 05.05. 2021

International Energy Agency (IEA) Global Energy Review 2021. (2021). https://www.iea.org/reports/global-energy-review-2021/co2emissions\#abstract. Accessed on 10.04. 2021. 